Page $181-192$

\title{
Pengaruh Permodalan, Kualitas Asset, Rentabilitas dan Likuiditas Terhadap Profitabilitas Bank Pembiayaan Rakyat Syariah (BPRS) di Indonesia

\author{
Widiya Ningsih', Tenny Badina ${ }^{2}$, Rita Rosiana ${ }^{3}$ \\ University of Sultan Ageng Tirtayasa \\ 'widiyawidningsih@gmail.com, ${ }^{2}$ tennybadina@gmail.com, ${ }^{3}$ rosiana_rita@yahoo.com
}

\begin{abstract}
The purpose of this study to analyze the influence of capital, asset quality, profitability and liquidity to profitabilitas. Population in this study is the Islamic Rural Bank (BPRS) registered at Bank Indonesia. Total sample of 12 selected by using purposive sampling, uses secondary data obtained through the website www.bi.go.id. The analytical method used in this research is Multiple Linear Regression and Software SPSS 22 as a tool to test the hypothesis. The results of this study are: capital, asset quality and liquidity does not affect the profitability, earnings negatively affect profitability.
\end{abstract}

Keywords: Islamic rural bank, profitability, multiple linier regressions

\begin{abstract}
Abstrak
Penelitian ini bertujuan untuk menganalisis pengaruh permodalan, kualitas aset, rentabilitas dan likuiditas terhadap profitabilitas. Populasi penelitian ini adalah Bank Pembiayaan Rakyat Syariah (BPRS) yang terdaftar di Bank Indonesia.Jumlah sampel sebanyak 12 BPRS yang dipilih dengan menggunakan metodepurposive sampling, menggunakan data sekunder yang diperoleh melalui website www.bi.go.id.Metode analisis yang digunakan adalah Analisis Regresi Linear Berganda dengan Software SPSS 22 sebagai alat bantu untuk menguji hipotesis. Hasil penelitian ini adalah: permodalan, kualitas aset dan likuiditas tidak berpengaruh terhadap profitabilitas, sedangkan rentabilitas berpengaruh negatif terhadap profitabilitas.
\end{abstract}

Kata Kunci: bank pembiayaan rakyat syariah, profitabilitas, regresi linier berganda.

Diterima: 12 Januari 2017; Revisi: 25 Februari 2017; Disetujui: 10 Maret 2017 


\section{PENDAHULUAN}

Bank Pembiayaan Rakyat Syariah (BPRS) dimaksudkan secara khusus untuk menjangkau masyarakat dari golongan ekonomi lemah dan pengusaha kecil yang perlu dibantu permodalannya. Pembiayaan oleh BPRS bisa memberikan pengaruh terhadap perbaikan ekonomi suatu wilayah, apabila usaha yang didanai dan dibina oleh BPRS bisa maju dan berkembang sehingga mampu mengangkat ekonomi masyarakat di sekitarnya (Suharso, 2015). Perkembangan BPRS di Indonesia selama kurun waktu 2012-2014 dapat terlihat dalam tabel berikut:

\section{Tabel I}

\section{Perkembangan Aset, DPK, dan Pembiayaan BPRS}

(dalam triliun rupiah)

\begin{tabular}{lccc}
\hline \multicolumn{1}{c}{ Indikator } & $\mathbf{2 0 I 2}$ & $\mathbf{2 0 1 3}$ & $\mathbf{2 0 I 4}$ \\
\hline Aset & 4,69 & 5,83 & 6,57 \\
DPK & 2,93 & 3,66 & 4,02 \\
Pembiayaan & 3,56 & 4,43 & 5,00 \\
\hline \multicolumn{2}{l}{ Sumber : Statistik Perbankan Syariah Indonesia, Desember 2014}
\end{tabular}

Berdasarkan Tabel I jumlah aset, DPK, dan pembiayaan terus meningkat tiap tahunnya selama tahun 2012-2014.Seiring dengan semakin berkembangnya BPRS, persaingan antar BPRS maupun bank konvensional semakin ketat, khususnya antar bank yang sejenis. Penelitian ini berusaha mengungkap kinerja BPRS dengan menganalisis secara empiris data tentang kinerja bank melalui rasio keuangannya. Tidak seluruh rasio CAMEL dapat digunakan untuk mengukur kinerja keuangan secara kuantitatif. Penilaian faktor Management bersifat kualitatif sehingga pada penelitian ini kinerja keuangan diukur melalui rasio CAEL (Capital, Asset Quality, Earning dan Liquidity). Data mengenai rasio-rasio keuangan BPRS dalam kurun waktu 2012-2014 dapat dilihat pada Tabel 2. 
Tabel 2

Rasio Keuangan BPRS

\begin{tabular}{cccc}
\hline Indikator & $\mathbf{2 0 1 2}$ & $\mathbf{2 0 1 3}$ & $\mathbf{2 0 1 4}$ \\
\hline ROA & $2,64 \%$ & $2,79 \%$ & $2,26 \%$ \\
CAR & $25,16 \%$ & $22,08 \%$ & $22,77 \%$ \\
NPF & $6,15 \%$ & $6,50 \%$ & $7,89 \%$ \\
BOPO & $80,02 \%$ & $80,75 \%$ & $87,79 \%$ \\
FDR & $120,96 \%$ & $120,93 \%$ & $124,24 \%$
\end{tabular}

Sumber : Statistik Perbankan Syariah, Desember 2014

Jika melihat pada Tabel I, selama periode 20I2-20I4 jumlah aset, DPK, dan pembiayaan BPRS terus mengalami kenaikan tiap tahunnya. Hal ini menunjukkan bahwa masyarakat mempercayai BPRS sebagai lembaga keuangan yang dipilih untuk memenuhi jasa keuangan yang dibutuhkan masyarakat. Namun berdasarkan Tabel 2 dapat diketahui bahwa ROA fluktuatif pada periode 20I220I4. Ketika jumlah aset, DPK, dan pembiayaan pada BPRS mengalami kecenderungan naik, ROA fluktuatif. Menentukan kebijakan-kebijakan yang tepat berkaitan dengan profitabilitas dan faktor-faktor yang mempengaruhinya menjadi hal yang sangat penting karena hubungan antara bank dengan nasabahnya di dalam sistem perbankan syariah bukan hubungan antara debitur dengan kreditur, melainkan hubungan kemitraan antara penyandang dana (shahib al maal) dengan pengelola dana (mudharib) (Muhamad, 20l4).

Pentingnya penelitian ini dilakukan karena informasi mengenai kinerja BPRS merupakan kepentingan semua pihak terkait, baik pemilik, pengurus bank, masyarakat pengguna jasa bank, dan Otoritas Jasa Keuangan selaku otoritas pengawasan bank maupun pihak lainnya (Darmawi, 20I I). Informasi tersebut dapat digunakan oleh pihakpihak yang berkepentingan untuk mengevaluasi kinerja BPRS dalam menerapkan prinsip kehatihatian, kepatuhan terhadap ketentuan yang berlaku dan manajemen risiko. Dipilihnya Bank Pembiayaan Rakyat Syariah sebagai obyek pengamatan karena penelitian yang mengeksplorasi kinerja keuangan bank terhadap profitabilitas pada Bank Pembiayaan Rakyat Syariah yang terdapat di www.bi.go.id secara menyeluruh masih jarang dilakukan. 


\section{KERANGKA TEORI}

\section{Profitabilitas (ROA)}

Profitabilitas merupakan rasio yang menggambarkan tentang kemampuan bank menghasilkan laba (Muhamad, 20I4).Pada penelitian ini, ROA digunakan sebagai ukuran profitabilitas bank. Return On Asset (ROA) adalah rasio yang menggambarkan kemampuan bank dalam mengelola dana yang diinvestasikan dalam keseluruhan aktiva yang menghasilkan keuntungan (Muhamad, 20I4). Semakin besar ROA suatu bank, semakin besar pula tingkat keuntungan yang dicapai bank tersebut sehingga akan meningkatkan profitabilitas bank dan semakin baik pula posisi bank tersebut dari segi penggunaan aset. (Dendawijaya, 2009).

\section{Permodalan (Capital)}

Modal adalah dana yang berasal dari pemilik bank atau pemegang saham ditambah dengan agio saham dan hasil usaha yang berasal dari kegiatan usaha bank (Dendawijaya, 2009:67). Pada penelitian ini Capital Adequacy Ratio (CAR) menjadi proksi dari permodalan. Capital Adequacy Ratio (CAR) adalah rasio kecukupan modal yang bertujuan untuk memastikan bahwa bank dapat menyerap kerugian yang timbul dari aktivitas yang dilakukannya (Idroes, 2008).

\section{Kualitas Aset (Asset Quality)}

Aktiva produktif menunjukkan kualitas aset sehubungan dengan risiko kredit yang dihadapi bank akibat pemberian kredit dan investasi dana bank pada portofolio yang berbeda. Pada penelitian ini Non Performing to Financing (NPF) menjadi proksi dari kualitas aset. Non Performing to Financing (NPF) pada perbankan syariah merupakan analog dari Non Performing Loan (NPL) pada bank konvensional. NPF adalah pembiayaan yang dikategorikan dalam tiga kualitas yaitu pertama pembiayaan dengan kualitas yang kurang lancar, kedua pembiayaan dengan kualitas yang diragukan dan ketiga pembiayaan macet atau yang biasa disebut dengan bad debt.

\section{Rentabilitas (Earning)}

Rasio rentabilitas adalah rasio yang digunakan untuk menganalisis kemampuan bank dalam menghasilkan profitabilitas selama periode tertentu dan untuk mengukur tingkat efektifitas manajemen dalam menjalankan operasional perusahaannya (Kasmir, 
2014). Pada penelitian ini Biaya Operasional terhadap Pendapatan Operasional (BOPO) menjadi proksi dari rentabilitas. BOPO adalah rasio yang menunjukkan tingkat efisiensi kinerja operasional bank (Muhamad, 20I4).

\section{Likuiditas (Liquidity)}

Rasio likuiditas merupakan rasio yang menggambarkan kemampuan perusahaan untuk menyelesaikan kewajiban jangka pendeknya (Harahap, 2009). Pada penelitian ini, likuiditas diproksikan oleh Financing to Deposit Ratio (FDR).Financing to Deposit Ratio (FDR) pada perbankan syariah merupakan analog dari Loan to Deposit Ratio (LDR) pada bank konvensional. FDR merupakan rasio antara total pembiayaan dengan dana pihak ketiga yang diterima oleh bank (Muhamad, 20I4).

\section{Pengembangan Hipotesis}

Permodalan diproksikan dengan Kewajiban Penyediaan Modal Minimum (KPMM) atau Capital Adequacy Ratio (CAR).CAR adalah gambaran mengenai kemampuan bank syariah untuk memenuhi kecukupan modalnya (Muhamad, 20I4).CAR sekaligus memberikan gambaran tentang kondisi modal yang dimiliki bank tersebut.Hal ini berarti, jika nilai CAR besar, semakin besar pula modal yang dimiliki bank sehingga bank dapat menjalankan kegiatan operasinya dengan baik.jika bank dapat menjalankan kegiatan operasinya dengan baik, maka dampaknya adalah peningkatan keuntungan. Teori ini didukung dengan penelitian yang dilakukan oleh Sudiyatno (2010), Schiniotakis (20I2) dan Petria, et.al (20I5) menunjukkan hasil bahwa CAR berpengaruh positif terhadap profitabilitas (ROA). Dengan demikian dapat dirumuskan hipotesis sebagai berikut:

HI : CAR berpengaruh positif terhadap profitabilitas (ROA).

Kualitas aset diproksikan dengan Non Performing to Financing (NPF).Non Performing to Financing (NPF) adalah pembiayaan yang dikategorikan dalam tiga kualitas yaitu pertama pembiayaan dengan kualitas yang kurang lancar, kedua pembiayaan dengan kualitas yang diragukan dan ketiga pembiayaan macet atau yang biasa disebut dengan bad debt. Bertambahnya NPF akan mengakibatkan hilangnya kesempatan bank untuk memperoleh pendapatan dari pembiayaan yang diberikan yang pada akhirnya menyebabkan ROA mengalami penurunan (Dendawijaya, 2009). Teori ini didukung oleh penelitian yang dilakukan oleh Arif dan Anees (2012) dan Petria et.al (2013) yang 
menunjukkan bahwa NPF berpengaruh negatif terhadap ROA. Dengan demikian dapat dirumuskan hipotesis sebagai berikut :

H2 : NPF berpengaruh negatif terhadap profitabilitas (ROA).

Rasio rentabilitas dalam penelitian ini menggunakan Biaya Operasional terhadap Pendapatan Operasional (BOPO).BOPO adalah rasio yang menunjukkan tingkat efisiensi kinerja operasional bank (Muhamad, 2014). Semakin tinggi tingkat rasio BOPO berarti semakin buruk kinerja manajemen bank tersebut, karena bank kurang efisien dalam menggunakan sumber daya yang ada di perusahaan. Teori ini didukung dengan penelitian yang dilakukan oleh Sudiyatno (2010), Schiniotakis (20I2), dan Suhardi dan Altin (2013) memberikan hasil yang berbeda, yaitu BOPO berpengaruh negatif terhadap profitabilitas (ROA). Dengan demikian dapat dirumuskan hipotesis sebagai berikut:

H3 : BOPO berpengaruh negatif terhadap profitabilitas (ROA).

Rasio likuiditas yang digunakan adalah Financing to Deposit Ratio (FDR).FDR merupakan rasio antara total pembiayaan yang diberikan bank dengan dana pihak ketiga yang diterima oleh bank (Muhamad, 20I4). Semakin rendah FDR menunjukkan bahwa bank kurang efektifitas dalam menyalurkan kredit. FDR yang rendah menunjukkan bank belum sepenuhnya mampu mengoptimalkan penggunaan dana masyarakat untuk melakukan ekspansi kredit. Semakin rendah FDR maka profitabilitas bank akan menurun. Teori ini didukung hasil penelitian Suhardi dan Altin (20/3) serta Riyadi dan Agung (20l4) menunjukkan bahwa FDR berpengaruh positif terhadap ROA. Dengan demikian dapat dirumuskan hipotesis sebagai berikut:

H4 : FDR berpengaruh positif terhadap profitabilitas (ROA).

\section{METODE}

Populasi dan Sampel

Populasi penelitian ini adalah 163 BPRS yang terdatar di ww.bi.go.id, penentuan sampel dengan metode purposive sampling dengan kriteria sebagai berikut: (I) BPRS yang mempublikasikan Laporan Keuangan di Bank Indonesia; (2) Laporan keuangan yang dipublikasikan lengkap selama periode 2012-2014; (3) Tidak mengalami kerugian selama periode pengamatan; (4) Laporan Keuangan telah diaudit per 3I Desember. 


\section{Metode Analisis}

Analisis data yang digunakan dalam penelitian ini yaitu pengujian asumsi klasik, uji kebaikan model dan analisis regresi berganda. Adapun model dasar dari regresi linear berganda dari penelitian ini dapat dirumuskan sebagai berikut :

$$
Y=a+B_{1} X_{1}+B_{2} X_{2}+B_{3} X_{3}+e
$$

Keterangan :

$\mathrm{Y} \quad=$ Return on Asset

a $=$ Konstanta persamaan regresi

b $\quad=$ Koefisien korelasi

$\mathrm{X}_{1} \quad=$ Capital Adequacy Ratio

$\mathrm{X}_{2}=$ Non Performing to Financing

$\mathrm{X}_{3}=$ Biaya Operasional terhadap Pendapatan Operasional

$\mathrm{X}_{4}=$ Financing to Deposit Ratio

\section{HASIL DAN PEMBAHASAN}

\section{Hasil Empiris}

Normalitas data menggunakan uji Kolmogorof Smirnov dan menunjukkan bahwa data berdistribusi normal, kemudian uji multikolonieritas variabel penelitian tidak terjadi multikolinieritas. Selanjutnya uji autokorelasi menunjukkan bahwa model regresi tidak terjadi autokorelasi dan dari uji heteroskedastisitas didapat model regresi juga tidak mengandung heteroskedastisitas.

Koefisien determinasi $\left(R^{2}\right)$ digunakan untuk mengukur seberapa jauh model dalam menerangkan variasi variabel independen.

\section{Tabel 3. Koefisien Determinasi}

Model Summary

\begin{tabular}{llrrr}
\hline Model & $R$ & R Square & $\begin{array}{c}\text { Adjusted R } \\
\text { Square }\end{array}$ & $\begin{array}{c}\text { Std. Error of the } \\
\text { Estimate }\end{array}$ \\
\hline $\mathrm{I}$ &, $642^{\mathrm{a}}$ & \multicolumn{1}{c}{, $4 \mathrm{I} 2$} &, 336 & $\mathrm{I}, 26439$ \\
\hline a. Predictors: (Constant), FDR, NPF, BOPO, CAR & \\
b. Dependent Variable: ROA \\
Sumber : Data sekunder yang diolah (2016)
\end{tabular}


Berdasarkan Tabel 3 menunjukkan besarnya adjusted $R^{2}$ adalah 0,336 . $\mathrm{Hal}$ ini berarti $33,6 \%$ variasi ROA dapat dijelaskan oleh variasi dari keempat variabel independen, yaitu CAR, NPF, BOPO, dan FDR. Sedangkan sisanya $(100 \%-33,6 \%=66,4 \%)$ dijelaskan oleh sebab-sebab yang lain diluar model.

Uji statistik $F$ digunakan untuk mengetahui apakah variabel independen secara bersama-sama atau simultan mempengaruhi variabel dependen. Berdasarkan Tabel 4 didapat nilai $F$ hitung sebesar 5,437 dengan probabilitas 0,002. Karena probabilitas lebih kecil dari 0,05 maka model regresi dapat digunakan untuk memprediksi ROA atau dapat dikatakan bahwa CAR, NPF, BOPO dan FDR secara bersama-sama berpengaruh terhadap ROA. Oleh karena itu, model penelitian ini baik untuk digunakan dan dapat dilanjutkan.

Tabel 4. Uji F

ANOVA $^{\mathrm{a}}$

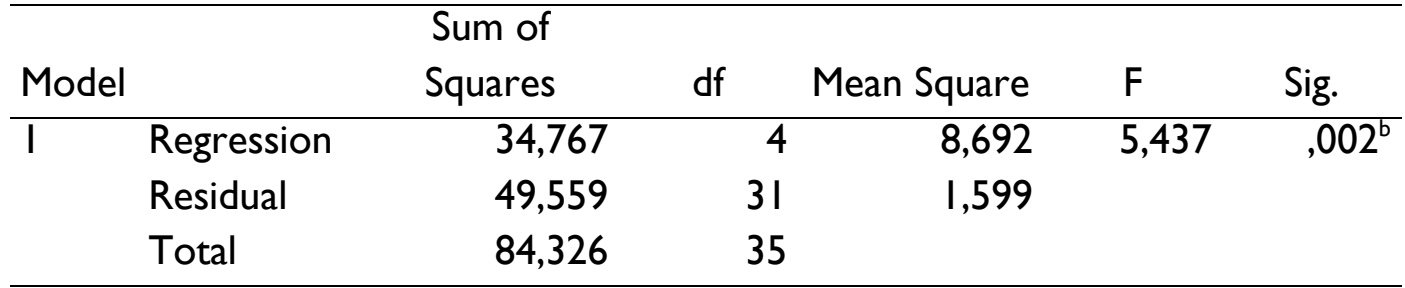

a. Dependent Variable: ROA

b. Predictors: (Constant), FDR, NPF, BOPO, CAR

Sumber : Data sekunder yang diolah (2016)

\section{Uji Regresi Linier Berganda}

Analisis statistik yang digunakan dalam penelitian ini yaitu regresi linear berganda. Analisis ini digunakan untuk mengetahui besarnya pengaruh variabelvariabel independen yaitu CAR, NPF, BOPO dan FDR terhadap variabel dependen yaitu ROA. dengan menggunakan SPSS 22,0 maka diperoleh hasil regresi sebagai berikut :

$$
Y=11,209-0,035 X_{1}+0,082 X_{2}-0,112 X_{3}+0,005 X_{4}
$$




\section{Tabel 5}

\section{Uji t}

\section{Coefficients $^{\mathrm{a}}$}

\begin{tabular}{|c|c|c|c|c|c|c|}
\hline \multirow{2}{*}{\multicolumn{2}{|c|}{ Model }} & \multicolumn{2}{|c|}{$\begin{array}{l}\text { Unstandardized } \\
\text { Coefficients }\end{array}$} & \multirow{2}{*}{$\begin{array}{c}\text { Standardized } \\
\text { Coefficients } \\
\text { Beta }\end{array}$} & \multirow[b]{2}{*}{$\mathrm{t}$} & \multirow[b]{2}{*}{ Sig. } \\
\hline & & $B$ & Std. Error & & & \\
\hline \multirow[t]{5}{*}{$\mathrm{I}$} & (Constant) & 11,209 & 1,983 & & 5,652 & , 000 \\
\hline & CAR &,- 035 & ,029 &,- 206 & $-1,216$ & ,233 \\
\hline & NPF & ,082 & ,069 & ,201 & 1,186 & ,245 \\
\hline & BOPO &,- 112 & ,025 &,- 648 & $-4,515$ & ,000 \\
\hline & FDR & ,005 & I & I & ,492 & 627 \\
\hline
\end{tabular}

a. Dependent Variable: ROA

Sumber : Data sekunder yang diolah (2016)

\section{Pembahasan}

Berdasarkan hasil uji statistik t pengujian variabel permodalan (CAR) terhadap profitabilitas (ROA) menunjukkan bahwa variabel permodalan (CAR) tidak berpengaruh terhadap profitabilitas (ROA). Adanya peraturan Bank Indonesia yang mengharuskan setiap bank untuk menjaga CAR dengan ketentuan minimal sebesar $8 \%$ membuat pihak bank untuk menjaga kecukupan modal bank. Oleh karena itu, pihak bank cenderung untuk menginvestasikan dananya dengan hati-hati dan tidak mudah mengeluarkan dana bank untuk pendanaan karena hal tersebut dapat memberikan risiko yang besar. Bank lebih menekankan pada sustainability bank sehingga CAR tidak berpengaruh terhadap profitabilitas bank.

Berdasarkan hasil uji statistik $t$ pengujian variabel kualitas aset (NPF) terhadap profitabilitas (ROA) menunjukkan bahwa variabel kualitas aset (NPF) tidak berpengaruh terhadap profitabilitas (ROA). NPF yang tidak berpengaruh terhadap ROA dikarenakan nilai rata-rata NPF pada BPRS memiliki nilai yang kecil.Selain itu, NPF yang tidak berpengaruh terhadap ROA dapat dikarenakan adanya tingkat pengelolaan operasional BPRS yang baik.Sehingga bertambahnya NPF pada bank menjadi tidak berpengaruh terhadap ROA karena bertambahnya NPF dibarengi dengan adanya efisiensi pengelolaan kinerja operasional bank. 
Berdasarkan hasil uji statistik t pengujian variabel rentabilitas (BOPO) terhadap profitabilitas (ROA) menunjukkan bahwa rentabilitas (BOPO) berpengaruh negatif terhadap profitabilitas (ROA). Semakin tinggi tingkat rasio BOPO maka ROA yang diperoleh menurun. Hal ini disebabkan karena tingkat efisiensi bank dalam menjalankan operasinya berpengaruh terhadap tingkat pendapatan atau earning yang dihasilkan bank tersebut. Tingginya beban biaya operasional bank yang menjadi tanggungan bank umumnya akan dibebankan pada pendapatan yang diperoleh dari alokasi pembiayaan. Beban yang semakin tinggi akan mengurangi permodalan dan laba yang dimiliki bank. Jika kondisi biaya operasional semakin meningkat tanpa dibarengi dengan pendapatan operasional maka akan berakibat berkurangnya ROA.

Berdasarkan hasil uji statistik $\mathrm{t}$ pengujian variabel likuiditas (FDR) terhadap profitabilitas (ROA) menunjukkan bahwa likuiditas (FDR) tidak berpengaruh terhadap profitabilitas (ROA). FDR yang tidak berpengaruh terhadap ROA disebabkan karena bank belum optimal dalam menyalurkan pembiayaan dimana dana pihak ketiga yang berupa simpanan dana masyarakat oleh bank masih digunakan atau ditempatkan pada penempatan antar bank yang tidak memerlukan cadangan penghapusan atau dianggap risikonya nol (Zulfikar, 20I4). Nilai rata-rata rasio FDR sebesar 87,9492 . Hal ini menunjukkan bahwa FDR yang dimiliki oleh BPRS di Indonesia masih dalam batas toleransi aman, yakni masih berada diantara 85\% dan 100\% (Dendawijaya, 2009). Namun perbankan syariah dinilai akanefektif untuk mendukung perolehan imbal hasil yang tinggi apabila FDR berada pada kisaran 95\%$98 \%$.

\section{Simpulan dan Saran}

Berdasarkan hasil analisis data dan pembahasan yang telah diuraikan, maka dapat ditarik kesimpulan sebagai berikut: (I) Hasil penelitian menunjukkan bahwa permodalan (CAR) tidak berpengaruh terhadap profitabilitas (ROA). Hal ini dapat terjadi karena pihak bank cenderung untuk menginvestasikan dananya dengan hati-hati serta lebih menekankan pada sustainability bank sehingga CAR tidak berpengaruh terhadap profitabilitas bank. (2) Hasil penelitian menunjukkan bahwa kualitas aset (NPF) tidak berpengaruh terhadap profitabilitas (ROA). Hal ini disebabkan karena proporsi 
pembiayaan bermasalah pada BPRS tidak begitu besar dan bertambahnya NPF dibarengi dengan adanya efisiensi pengelolaan kinerja operasional bank sehingga tidak mempengaruhi ROA. (3) Hasil penelitian menunjukkan bahwa rentabilitas (BOPO) berpengaruh negatif terhadap profitabilitas (ROA). Hal ini menunjukkan bahwa BPRS yang memiliki rasio BOPO yang kecil akan mampu meningkatkan profitabilitasnya karena bank telah efisien dalam menggunakan sumber daya yang ada di perusahaan. (4) Hasil penelitian menunjukkan bahwa likuiditas (FDR) tidakberpengaruh terhadap profitabilitas (ROA). Hal ini menunjukkan bahwa bank belum optimal dalam menyalurkan dana simpanan masyarakat dalam bentuk pembiayaan.

\section{PUSTAKA ACUAN}

Arif, Ahmed dan Ahmed Nauman Anees. 2012. Liquidity risk and Performance of Banking System. Journal of Financial Regulation and Compliance. Vol.20; 182-195.

Darmawi, Herman. 20I I. Manajemen Perbankan. Jakarta:PT Bumi Aksara.

Dendawijaya, L. 2009. Manajemen Perbankan. Bogor: Ghalia Indonesia.

Ghozali, Imam. 20II. Aplikasi Analisis Multivariate Dengan Program SPSS. Semarang : BP Universitas Diponegoro.

Kasmir. 2014. Analisis laporan keuangan. Depok: Rajawali Pers.

Muhamad. 20I4. Manajemen Dana Bank Syariah. Jakarta:Rajawali Pers.

Petria, Nicolae, et.al. 2015. Determinants of Banks' Profitability: Evidence from EU 27 banking systems. Procedia Economics and Finance (20) ; 518-524.

Schiniotakis loanni, Nikos. 2012. Profitability factors and efficiency of Greek Banks. Euro Med Journal of Business. Vol.7: 185-200.

Sudiyatno, Bambang. 2010. Analisis Pengaruh Dana Pihak Ketiga, BOPO, CAR, dan LDR terhadap Kinerja Keuangan pada Sektor Perbankan yang Go Public di Bursa Efek Indonesia (BEI) periode 2005-2008. Dinamika Keuangan dan Perbankan, Vol. 2, No. 2, I25-I37. 
Wibowo, Edhi Satriyo dan Muhammad Syaichu. 2013. Analisis Pengaruh Suku Bunga, Inflasi, CAR, BOPO, NPF terhadap Profitabilitas Bank Syariah. Diponegoro Journal of Accounting. Vol. 2, No. 2 : I-I0. 